\title{
PENYULUHAN DALAM MEMINIMALISIR PEMBUANGAN SAMPAH UNTUK PENGEMBANGAN OBJEK WISATA DI PANTAI PANDAN CARITA KABUPATEN TAPANULI TENGAH
}

\author{
COUNSELING IN MINIMIZING WASTE DISPOSAL \\ FOR THE DEVELOPMENT OF TOURISM OBJECT \\ AT PANDAN CARITA BEACH, CENTRAL TAPANULI DISTRICT
}

\author{
Esi Wahyuni*, Nur Aina, Anjali Kristina, Poniman, Emma Suri Yanti Siregar, \\ Insaniah Rahimah
}

\author{
Sekolah Tinggi Perikanan dan Kelautan Matauli \\ *Email: esiwahyuni8@gmail.com \\ (Diterima 28-01-2021; Disetujui 22-02-2021)
}

\begin{abstract}
ABSTRAK
Sampah merupakan suatu bahan yang dibuang atau terbuang sebagai hasil dari aktifitas manusia maupun hasil aktifitas alam yang tidak atau belum memiliki nilai ekonomis. Persoalan sampah tidak henti hentinya untuk dibahas, karena berkaitan dengan pola hidup serta budaya masyarakat. Tapanuli Tengah adalah salah satu kabupaten yang memiliki potensi luar biasa dalam bidang wisata bahari, terutama pada pulau-pulau dan pantai yang indah. Hal ini menjadikan Kabupaten Tapanuli Tengah unggul dalam bidang wisata bahari. Akan tetapi, permasalahan utama mengenai sampah tetap menjadi sebuah permasalahan yang belum terselesaikan hingga saat ini. Kegiatan penyuluhan ini bertujuan untuk memberikan edukasi/kesadaran kepada masyarakat serta wisatawan Pantai Pandan Carita tentang: (1) Bahaya sampah (terutama plastik), (2) Cara menjaga kebersihan pantai, dan (3) Cara pengelolaan sampah. Kegiatan ini dilakukan dengan metode ceramah, diskusi dan tanya jawab dengan menggunakan media flift chart. Hasil dari kegiatan ini adalah: (1) Media yang digunakan untuk kegiatan penyuluhan berupa flift chart tentang sampah dan efeknya terhadap kehidupan, (2) Hasil observasi, diskusi dan tanya jawab, menunjukkan bahwa melalui kegiatan penyuluhan ini pengetahuan masyarakat tentang bahaya sampah terhadap kehidupan, dan (3) Kesadaran masyarakat terhadap bahaya sampah terhadap kehidupan.
\end{abstract}

Kata kunci: Wisata Bahari, Penyuluhan, Kesadaran

\section{ABSTRACT}

Waste is a material that is thrown away or thrown away as a result of human activities or natural activities that do not or do not have economic value. The issue of waste continues to be discussed, because it is related to the lifestyle and culture of the community. Central Tapanuli is one of the districts that has extraordinary potential in the field of marine tourism, especially on beautiful islands and beaches. This makes Tapanuli Tengah Regency superior in the marine tourism sector. However, the main problem regarding waste remains an unresolved problem until now. Activities have been carried out aimed at providing education / awareness to the public and tourists of Pandan Carita Beach about: (1) The dangers of waste (especially plastics), (2) How to keep the beach clean (3) How to manage waste. This activity is carried out using the method of lecturing, discussion and question and answer using the flift chart media. The results of this activity are: (1) The media used for extension activities is in the form of flift charts about waste and its effects on life, (2) The results of observations, discussions and questions and answers show that through this extension activity, public knowledge about the dangers of waste to life, and 3) Public awareness of the dangers of waste to life.

Keywords : Marine tourism, Education, Awareness

\section{PENDAHULUAN}

Pertumbuhan ekonomi merupakan salah satu indikator yang menjadi perhatian penting bagi suatu negara termasuk Indonesia. Pertumbuhan ekonomi Indonesia terus berkembang dan menunjukkan angka perbaikan dalam meningkatkan pendapatan atau 
Penyuluhan Dalam Meminimalisir Pembuangan Sampah Untuk Pengembangan Objek Wisata Di Pantai Pandan Carita Kabupaten Tapanuli Tengah

Esi Wahyuni, Nur Aina, Anjali Kristina, Poniman, Emma Suri Yanti Siregar, Insaniah Rahimah

devisa negara. Salah satu sektor tersebut adalah pariwisata yang saat ini telah berkembang dan menjadi industri terbesar bagi pertumbuhan ekonomi di Indonesia, ini dapat dilihat dari meningkatnya perkembangan jumlah kunjungan wisatawan nusantara maupun mancanegara.

Sektor pariwisata berperan penting dalam meningkatkan perekonomian suatu negara, khususnya dalam mengurangi jumlah pengangguran dan meningkatkan produktivitas suatu negara (Jaffe \& Pasternak, 2004). Sektor pariwisata merupakan salah satu sektor strategis yang harus dimanfaatkan untuk pembangunan kepariwisataan sebagai bagian dari pembangunan nasional. Pembangunan kepariwisataan mempunyai tujuan akhir untuk meningkakan pendapatan masyarakat yang pada akhirnya dapat meningkatkan kesejahteraan masyarakat dan pertumbuhan ekonomi.

Upaya dalam penyuksesan dan pemaksimalan kegiatan pariwisata, dewasa ini kian gencar dilaksanakan di Provinsi Sumatra Utara terutama Kabupaten Tapanuli Tengah yang terus berbenah dengan adanya perkembangan teknologi dan informasi yang ada. Namun, kabupaten ini masih mengalami kesulitan dalam mengatasi permasalahan sampahnya. Ini dapat dilihat dari penyebaran sampah yang terdapat di sekitar Pantai Pandan Carita, Kabupaten Tapanuli Tengah yang juga menjadi tempat penyuluhan berlangsung. Sehingga dengan adanya permasalahan utama ini, sangat berpengaruh terhadap jumlah wisatawan asing atau pengunjung yang semakin menurun kuantitasnya dikarenakan kenyamanan dan kesehatan para pengunjung menjadi terancam.

Meningkatnya jumlah sampah tanpa melakukan pencegahan peningkatan sampah yang tepat diperkirakan dapat menjadikan tidak terciptanya lingkungan yang bersih dan indah, disebabkan masih banyak sampah yang berhamburan di pesisir pantai karena tidak adanya tempat pembuangan sampah yang memadai. Selain itu, kebanyakan masyarakat dan wisatawan yang berkunjung ke Pantai Pandan Carita membuang sampah di sepanjang pesisir pantai, mengakibatkan hilangnya keindahan dan keelokan pantai yang seharusnya menjadi objek wisata bagi para pengunjung, dan pada umumnya masyarakat yang tinggal di pesisir pantai sering membuang sampah di laut, sehingga mengakibatkan masalah pencemaran lingkungan.

Di Indonesia, sampah laut menjadi masalah besar dan dilaporkan sebagai produsen sampah plastik ke laut terbesar kedua setelah Cina (Jambeck, 2015). Menurut Kementerian Lingkungan Hidup (KLH), setiap hari orang Indonesia menghasilkan 0,8 $\mathrm{kg}$ sampah atau 189 ribu ton sampah per hari. Sebagian dari total sampah ini dibuang langsung ke perairan dan akhirnya berada di laut. Akumulasi sampah di laut disebabkan oleh pembuangan 
sampah oleh masyarakat yang disebabkan karena kurangnya pengetahuan masyarakat tentang sampah yang mengakibatkan jumlah sampah yang semakin meningkat. Penanganan sampah memerlukan partisipasi aktif individu dan kelompok masyarakat selain peran pemerintah sebagai fasilitator. Dengan meningkatnya kualitas lingkungan laut yang bebas dari sampah maka kualitas hidup masyarakat meningkat (Marojahan, 2015).

Sehubungan dengan hal tersebut di atas, Pantai Pandan Carita telah difasilitasi berbagai bangunan oleh pemerintah daerah sebagai daerah wisata. Berdasarkan hasil pengamatan lokasi wisata tersebut cukup menarik karena menghadap matahari terbenam dan hamparan pantai yang cukup luas. Kendala yang dihadapi adalah masih adanya masyarakat yang bermukin di pantai tersebut belum mengelola sampah dengan baik. Di samping itu, sampah laut yang terbawa arus dari luar juga menambah banyaknya kumulasi sampah di pantai. Ditambah lagi penyediaan fasilitas pembungan sampah yang kurang memadai. Apabila keadaan tersebut dibiarkan maka tujuan pemerintah untuk menjadikan pantai wisata dapat terhambat.

Kegiatan penyuluhan dilakukan dengan tujuan untuk memberikan edukasi/kesadaran kepada masyarakat Pantai Pandan Carita: (1) Bahaya sampah (terutama plastik), (2) Cara menjaga kebersihan pantai, dan (3) Cara pengelolaan sampah. Manfaat yang diperoleh dari kegiatan ini adalah sebagai berikut: (1) Dengan timbulnya kesadaran masyarakat pesisir terhadap kebersihan pantai terutama akibat sampah, diharapkan dapat mendukung program pemerintah terhadap kebersihan laut. (2) Dengan adanya kegiatan ini diharapkan dapat dijadikan dasar bagi instansi terkait terutama pemerintah daerah (Pemda) dalam upaya pengelolaan sampah di pantai.

\section{BAHAN DAN METODE}

\section{Waktu dan Tempat}

Penyuluhan ini dilaksanakan pada hari Sabtu, 05 Desember 2020 di kawasan Pantai Pandan Carita dan sekitarnya Kecamatan Pandan Kabupaten Tapanuli Tengah Provinsi Sumatera Utara. Kecamatan Pandan sebelah utara berbatasan dengan Kecamatan Sarudik, sebelah selatan berbatasan dengan Kecamatan Badiri, sebelah barat berbatasan dengan Samudera Indonesia dan sebelah timur berbatasan dengan Kecamatan Tukka (BPS Pandan, 2018).

\section{Alat dan Bahan}

Alat dan Bahan yang digunakan pada saat penyuluhan adalah alat peraga berupa flift chart yang berfungsi sebagai alat bantu penyampaian materi serta membantu sasaran 
Penyuluhan Dalam Meminimalisir Pembuangan Sampah Untuk Pengembangan Objek Wisata Di Pantai Pandan Carita Kabupaten Tapanuli Tengah

Esi Wahyuni, Nur Aina, Anjali Kristina, Poniman, Emma Suri Yanti Siregar, Insaniah Rahimah

dalam memahami materi yang disampaikan oleh penyuluh, alat tulis digunakan untuk mencatat absensi sasaran penyuluhan, kertas digunakan sebagai bahan absensi, kamera sebagai bahan dokumentasi kegiatan selama berlangsungnya kegiatan penyuluhan serta laptop digunakan untuk analisis data.

\section{Teknik Pengumpulan Data}

Teknik pengumpulan data yang dilakukan dalam penyuluhan ini yaitu dengan teknik observasi, wawancara serta dokumentasi.

a. Observasi

Menurut Satori \& Komariah (2011), observasi adalah pengamatan terhadap suatu objek yang diteliti baik secara langsung maupun tidak langsung untuk memperoleh data yang harus dikumpulkan dalam penelitian. Secara langsung dengan terlibat ke lapangan dengan melibatkan seluruh pancaindera. Sedangkan tidak langsung dengan dibantu media visual/audiovisual.

Observasi bisa diartikan sebagai pengamatan dan pencatatan secara sistematik terhadap gejala yang tampak pada hal yang akan diamati. Pengamatan ini dilakukan untuk melihat kebersihan di Pantai Pandan Carita dan sekitarnya untuk mendapatkan data yang lebih akurat.

b. Wawancara

Wawancara ialah tanya jawab lisan antara dua orang atau lebih secara langsung berguna untuk mendapatkan data dari tangan pertama (primer), pelengkap teknik pengumpulan lainnya, menguji hasil pengumpulan data lainnya (Usman \& Akbar, 2009), sedangkan Menurut Sugiyono (2010), bahwa wawancara digunakan sebagai teknik pengumpulan data apabila peneliti ingin melakukan studi pendahuluan untuk menemukan permasalahan yang harus diteliti, dan juga mengetahui hal-hal dari responden yang lebih mendalam dan jumlah respondennya kecil atau sedikit.

Penyuluh langsung melakukan proses penyuluhan terhadap sasaran penyuluhan dengan cara menyampaikan materi serta melakukan diskusi atau tanya jawab dengan sasaran penyuluhan untuk mengetahui hal-hal dari sasaran penyuluhan yang lebih mendalam.

c. Dokumentasi

Dokumentasi dimaksudkan memperoleh data dengan cara mempelajari data yang berkaitan dengan penyuluhan seperti materi dan gambar yang digunakan sebagai alat penyampaian kepada sasaran penyuluhan. 


\section{Analisis Data}

Proses analisis data yang dilakukan adalah sebagai berikut:

a. Editing, yaitu kegiatan memeriksa dan meneliti kembali data-data yang telah diperoleh dari hasil observasi dan wawancara, untuk mengetahui apakah data yang ada sudah cukup dan lengkap serta dapat dipahami.

b. Kategorisasi, yaitu semua data yang telah diperoleh kemudian dikelompokkan sesuai dengan jenis dan kronologis permasalahan yang diteliti.

c. Interprestasi data, yaitu penafsiran atau menjelaskan data-data yang telah diperoleh di lapangan dalam bentuk penggambaran kata-kata, tanpa mengubah maksud data tersebut.

Kemudian pada proses selanjutnya untuk menganalisis data yang telah diperoleh. Penyuluh menggunakan kualitatif deskriptif, yaitu yang memberikan gambaran mengenai hasil kegiatan penyuluhan yang dilakukan mengenai penyuluhan dalam meminimalisir pembuangan sampah sembarangan untuk pengembangan objel wisata di Pantai Pandan Carita Kabupaten Tapanuli Tengah.

\section{HASIL DAN PEMBAHASAN}

Berdasarkan hasil kegiatan penyuluhan yang dilakukan di Pantai Pandan Carita, hasil interaksi antara masyarakat serta wisatawan yang sedang berkunjung di Pantai Pandan Carita tersebut bahwa pantai tersebut sering dikunjungi oleh masyarakat setempat maupun wisatawan dari luar kota. Berdasarkan observasi awal penyuluh pertama-tama melihat lingkungan yang ada di sekitar pantai. Pantai Pandan Carita merupakan salah satu objek wisata pantai yang ada di Kabupaten Tapanuli Tengah, Sumatera Utara yang banyak dikunjungi oleh wisatawan dari dalam maupun luar kota, tetapi untuk masalah kebersihan Pantai Pandan Carita masih kurang. Banyak pengunjung yang masih membuang sampah di sembarang tempat.

Sampah merupakan suatu bahan yang dibuang atau terbuang sebagai hasil dari kegiatan sehari-hari manusia maupun hasil kegiatan dari alam yang berbentuk padat serta belum atau tidak memiliki nilai ekonomis. Membuang sampah sembarangan merupakan salah satu perilaku yang mengakibatkan banyak dampak negatif yang ditimbulkan seperti banjir, wabah penyakit, dan tentunya kerusakan lingkungan yang lainnya. Darmono (2010) menyatakan bahwa beberapa dampak lainnya adalah terjadinya pencemaran udara yang merusak lapisan ozon sehingga menimbulkan pemanasan global; pencemaran air yang berupa pencemaran substansi kimia dan radioaktif yang mengganggu fauna misalnya 
Penyuluhan Dalam Meminimalisir Pembuangan Sampah Untuk Pengembangan Objek Wisata Di Pantai Pandan Carita Kabupaten Tapanuli Tengah

Esi Wahyuni, Nur Aina, Anjali Kristina, Poniman, Emma Suri Yanti Siregar, Insaniah Rahimah

keracunan hingga terjadinya kerusakan genetik dan gangguan reproduksi atau perkembangbiakan dan perpindahan emisi logam yang mempengaruhi kesehatan makhluk hidup.

Penyebab banyaknya sampah di lokasi pantai tersebut yakni kurangnya kesadaran pengunjung akan membuang sampah pada tempatnya, padahal terdapat beberapa tempat sampah meskipun masih kurang memadai di Pantai Pandan Carita untuk menanggulangi wisatawan membuang sampah pada tempatnya. Kurangnya kebersihan pantai dapat menurunkan minat para wisatawan untuk berkunjung ke pantai maka dilakukan penyuluhan kepada masyarakat setempat maupun wisatawan yang sedang berkunjung di pantai tersebut untuk dapat meminimalisir pembuangan sampah sembarangan di Pantai Pandan Carita, Kabupaten Tapanuli Tengah, Sumatera Utara. Tindakan dilakukan dengan cara memberikan penyuluhan berupa edukasi mengenai sampah, macam-macam sampah, bagaimana cara pengelolaan sampah, bahaya sampah bagi kesehatan serta dampak negative dari sampah terhadap kehidupan laut dan manusia.

Kegiatan pertama penyuluhan diawali dengan meminta izin terlebih dahulu kepada sasaran penyuluh, kemudian setelah diberi izin penyuluh langsung menyajikan gambar dalam bentuk flift chart untuk dapat menarik minat dari sasaran untuk mendengarkan penjelasan dari penyuluh terkait sampah dan diakhiri dengan diskusi atau tanya jawab. Penyajian gambar pertama adalah Gambar 1 yang menggambarkan definisi dari sampah.
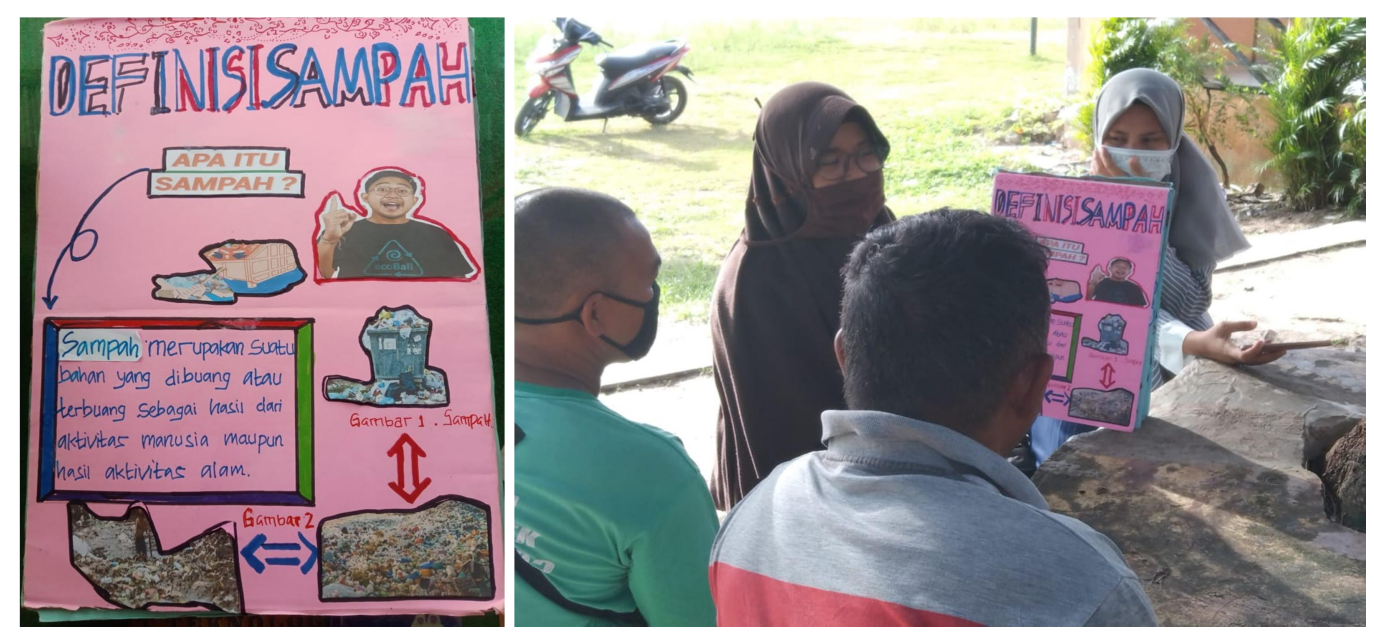

Gambar 1. Suasana Penjelasan Definisi Sampah

Sasaran penyuluhan diarahkan untuk memperhatikan gambar dengan durasi waktu 35 menit, kemudian sasaran mengamati gambar tersebut. Gambar 1 menunjukkan bahwa penyuluh menjelaskan definisi sampah kepada sasaran penyuluhan. Sampah merupakan 
suatu bahan yang dibuang atau terbuang sebagai hasil dari kegiatan sehari-hari manusia maupun hasil kegiatan dari alam yang berbentuk padat serta belum atau tidak memiliki nilai ekonomis. Tahap berikutnya penyajian gambar kedua adalah Gambar 2 yang menggambarkan mengenai jenis-jenis dari sampah.
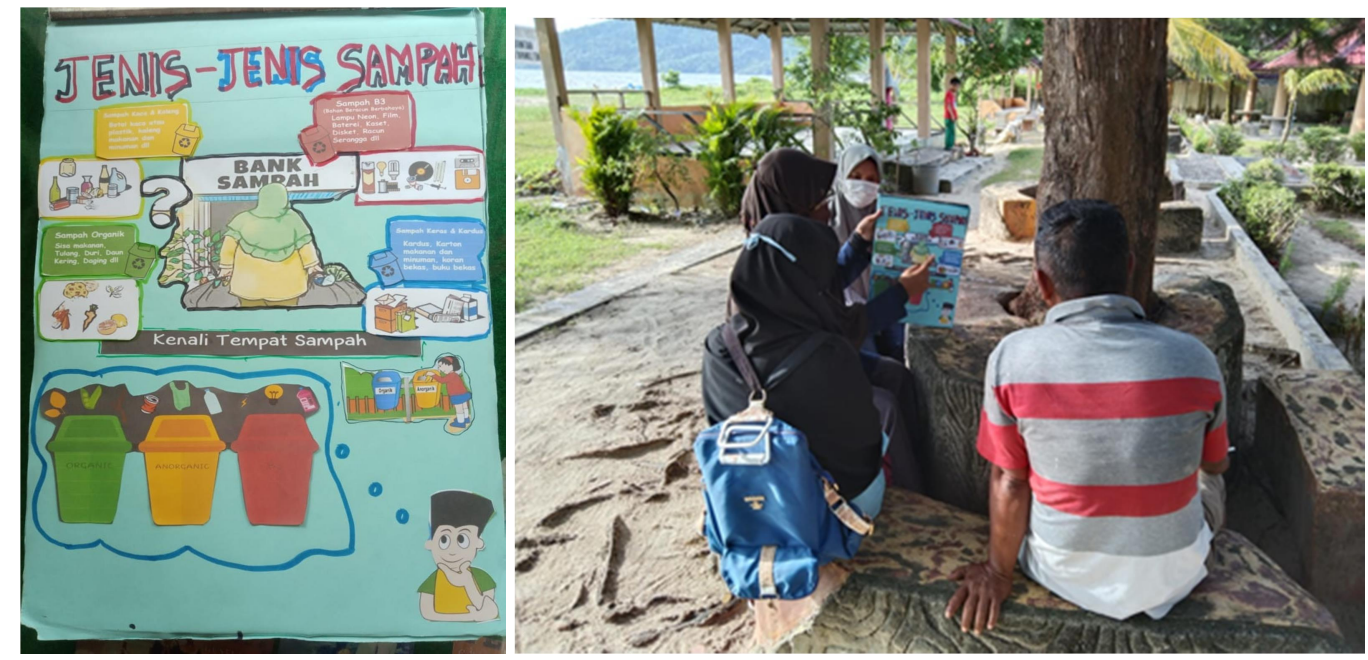

Gambar 2. Suasana Penjelasan Jenis-Jenis Sampah

Gambar 2 menunjukkan bahwa penyuluh memberikan informasi kepada sasaran mengenai jenis-jenis sampah berupa sampah organik (sampah yang berasal dari sisa makanan, tulang, duri, daun kering, daging, dan lain sebagainya), kemudian sampah anorganik (sampah yang berasal dari plastik, botol kaca, kaleng makanan dan minuman, dan lain sebagainya) serta sampah bahan beracun dan berbahaya (sampah yang berasal dari lampu neon, film, baterai, kaset, racun serangga, dan lain sebagainya). Tahap berikutnya penyajian gambar ketiga adalah Gambar 3 yang menggambarkan mengenai sumbersumber sampah.
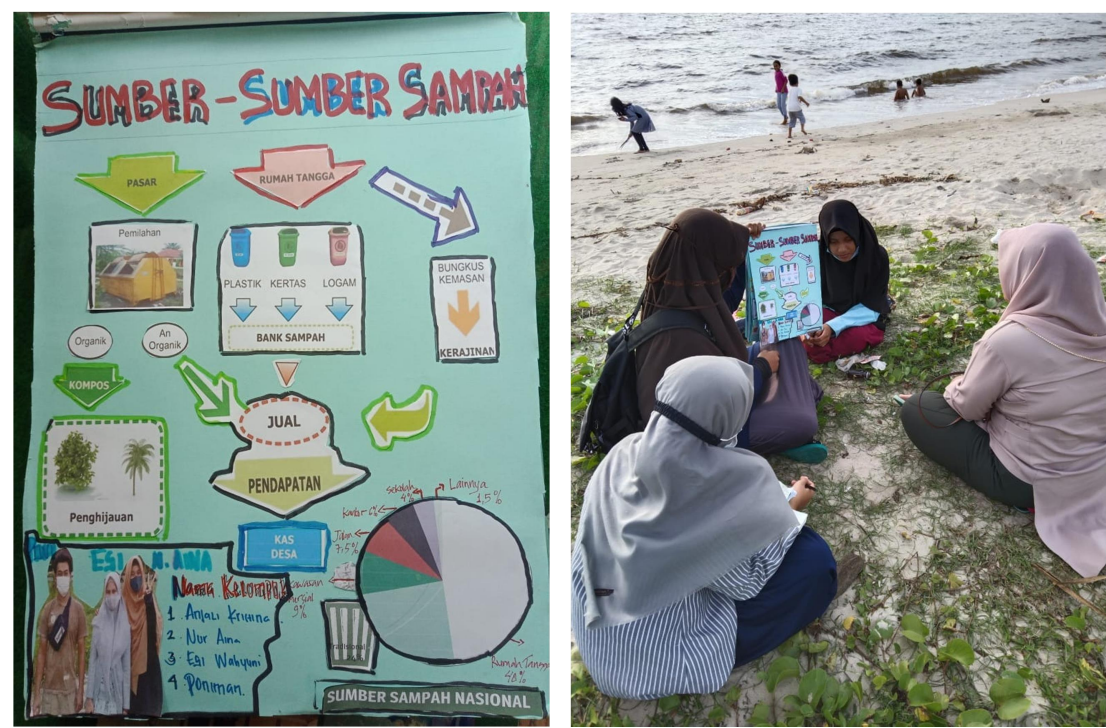

Gambar 3. Suasana Penjelasan Sumber-Sumber Sampah 
Penyuluhan Dalam Meminimalisir Pembuangan Sampah Untuk Pengembangan Objek Wisata Di Pantai Pandan Carita Kabupaten Tapanuli Tengah

Esi Wahyuni, Nur Aina, Anjali Kristina, Poniman, Emma Suri Yanti Siregar, Insaniah Rahimah

Gambar 3 menunjukkan bahwa penyuluh memberikan informasi kepada sasaran mengenai sumber-sumber sampah. Sumber sampah yang paling utama berasal dari sampah rumah tangga kemudian sampah yang berasal dari pasar, kawasan komersial, jalan, kantor, sekolah serta yang lainnya. Tahap berikutnya penyajian gambar keempat adalah Gambar 4 yang menggambarkan mengenai bagaimana cara pengelolaan sampah yang baik dan benar.
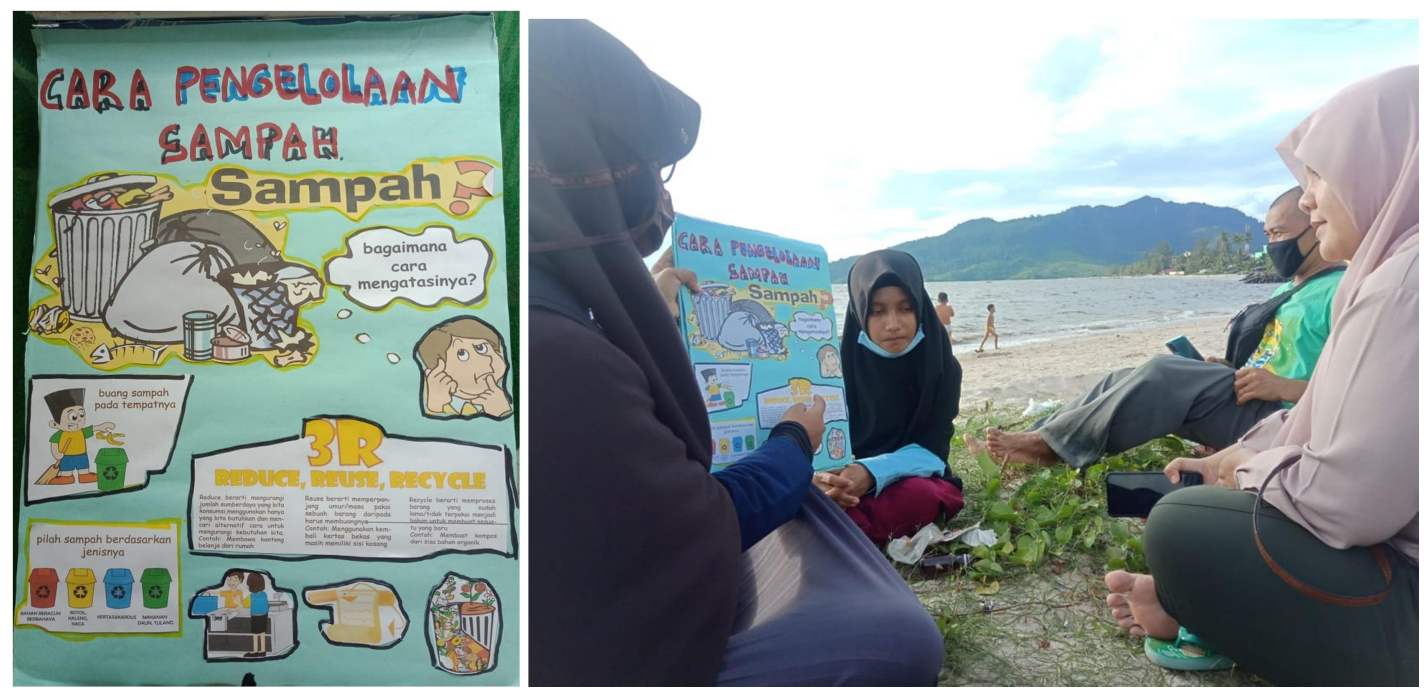

Gambar 4. Suasana Penjelasan Cara Pengelolaan Sampah

Gambar 4 menunjukkan bahwa penyuluh memberikan informasi kepada sasaran mengenai bagaimana cara pengelolaan sampah yang baik dan benar. Cara mengatasi sampah yaitu dengan cara melakukan pilah sampah berdasarkan jenis sampahnya serta tentunya harus membuang sampah pada tempatnya. Cara pengelolaan sampah dilakukan dengan 3R, yakni Reduce dengan cara mengurangi jumlah sumberdaya yang kita konsumsi, Reuse dengan cara menggunakan kembali barang yang telah dipakai daripada harus membuangnya dan Recycle dengan cara memproses barang yang sudah tidak terpakai menjadi bahan untuk membuat sesuatu yang baru. Tahap berikutnya penyajian gambar kelima adalah Gambar 5 yang menggambarkan mengenai dampak-dampak bahaya yang diakibatkan dari adanya sampah. 

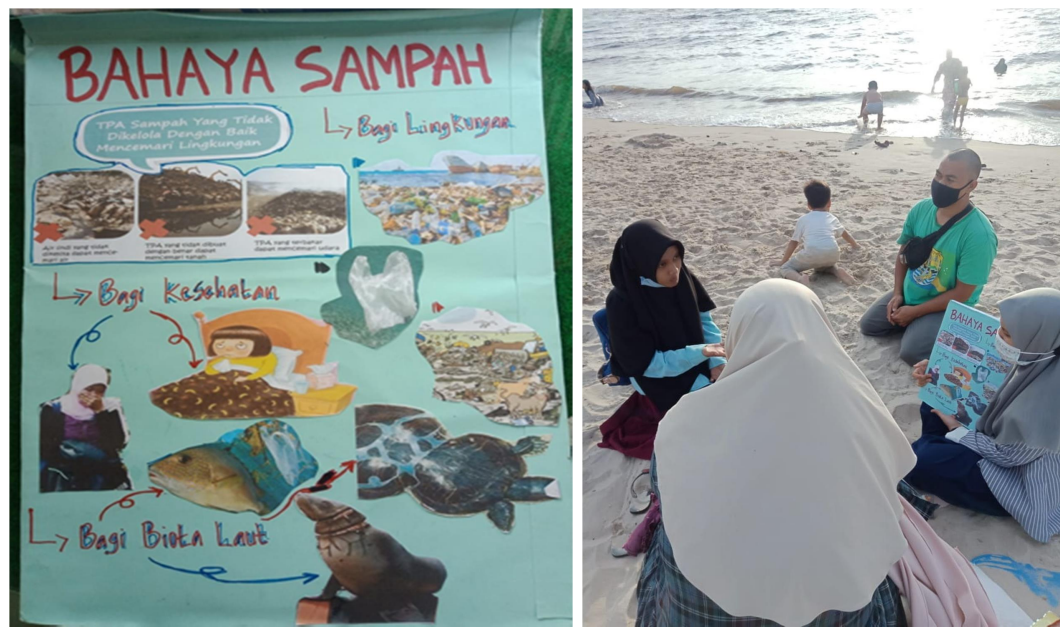

Gambar 5. Suasana Penjelasan Bahaya Sampah

Gambar 5 menunjukkan bahwa penyuluh memberikan informasi kepada sasaran mengenai bahaya dari sampah terhadap lingkungan yang menjadi kotor yang mengakibatkan bahaya terhadap kesehatan terutama bagi anak kecil seperti diare, malaria, demam berdarah, dan lain sebagainya; serta bahaya bagi biota yang ada di laut yang mengakibatkan biota laut akan mati yang mengira sampah plastik sebagai makanannya dan tumpukan sampah di laut mencemari kejernihan dan kesegaran air laut. Tahap terakhir adalah tahap diskusi atau tanya jawab, dari hasil penyuluhan yang dilakukan maka sasaran lebih mengetahui lebih jelas mengenai sampah, jenis-jenis sampah, sumber-sumber sampah, bagaimana cara pengelolaan sampah, serta juga bahaya dari sampah terhadap lingkungan, kesehatan serta kehidupan biota laut.

Tujuan utama kegiatan penyuluhan ini adalah untuk dapat membangkitkan kesadaran masyarakat setempat maupun wisatawan agar menjaga kebersihan lingkungan pantai agar tidak membuang sampah langsung ke pantai serta tidak membuang sampah sembarangan, mengingat bahwa bahaya yang ditimbulkan akibat membuang sampah sembarangan seperti terganggunya ekosistem yang ada di laut. Menurut Murianto \& Masyhudi (2018), pergeseran konsep kepariwisataan saat ini menuju ekowisata merupakan peluang besar bagi wilayah dengan potensi alam. Hal ini terjadi karena kecederungan semakin banyaknya wisatawan yang mengunjungi objek yang berbasis alam, budaya dan penduduk lokal.

Kebersihan lingkungan pantai merupakan salah satu daya tarik wisatawan untuk dapat berkunjung pada suatu wisata bahari, jika Pantai Pandan Carita kebersihan lingkungannya terjaga maka wisatawan akan berbondong-bondong untuk mengunjungi Pantai Pandan Carita untuk dapat menikmati sunset pada sore hari serta melakukan rekreasi pantai lainnya. Apabila banyak pengunjung yang datang ke Pantai Pandan Carita 
Penyuluhan Dalam Meminimalisir Pembuangan Sampah Untuk Pengembangan Objek Wisata Di Pantai Pandan Carita Kabupaten Tapanuli Tengah

Esi Wahyuni, Nur Aina, Anjali Kristina, Poniman, Emma Suri Yanti Siregar, Insaniah Rahimah

secara tidak langsung dapat meningkatkan pendapatan asli daerah itu sendiri. Selain itu, masyarakat di sekitar pantai tersebut dapat memperoleh keuntungan karena adanya lapangan pekerjaan yang akan meningkatkan pendapatan kesejahteraan masyarakat sekitar (Ferdinan, 2010). Dampak positif dari sebuah wisata menurut Hijriati dan Mardiana (2014) yaitu menciptakan kesempatan berusaha, meningkatkan kesadaran masyarakat mengenai pemanfaatan objek wisata, meningkatkan upaya pelestarian lingkungan dan, meningkatnya promosi penggunaan sumber daya alam secara berkelanjutan.

\section{KESIMPULAN DAN SARAN}

\section{Kesimpulan}

Hasil dari kegiatan pengabdian kepada masyarakat ini dapat diambil kesimpulan bahwa media yang digunakan untuk kegiatan penyuluhan berupa flift chart tentang sampah, jenis-jenis sampah, sumber-sumber sampah, cara pengelolaan sampah dan efeknya terhadap kehidupan. Hasil observasi, diskusi dan tanya jawab, menunjukkan bahwa melalui kegiatan penyuluhan ini pengetahuan masyarakat tentang sampah serta bahaya sampah terhadap kehidupan semakin meningkat dan kesadaran masyarakat terhadap bahaya sampah terhadap kehidupan juga semakin tinggi.

\section{Saran}

Saran untuk kegiatan selanjutnya adalah untuk memperoleh cara yang efektif dan efesien dalam menyampaikan materi agar sasaran penyuluhan mengetahui informasiinformasi yang disampaikan dengan jelas. Cara penyampaian materi oleh penyuluh cukup menarik serta kreatif, tetapi jumlah sasaran penyuluh cukup minim sehingga diperlukan cara untuk dapat meningkatkan jumlah sasaran penyuluhan seperti melakukan penyuluhan dengan cara kelompok dengan jumlah sasaran yang terjangkau agar penyampaian informasi dapat dipahami oleh para sasaran. Penyuluh berharap untuk ke depannya mampu memperoleh cara yang efektif dalam penyampaian materi penyuluhan.

\section{DAFTAR PUSTAKA}

Aan Komariah, Djam'an Satori. (2011). Metode Penelitian Kualitatif. Bandung: Alfabeta. Akbar dan Usman. (2009). Metode Penelitian Sosial. Jakarta: Bumi Aksara.

Badan Pusat Statistik Kabupaten Tapanuli Tengah. (2018). Data Kecamatan Pandan Kabupaten Tapanuli Tengah. Kabupaten Tapanuli Tengah: Badan Pusat Statistik Kabupaten Tapanuli Tengah.

Ferdinan, F. (2010). Pengembangan Wisata Alam Berbasis Ekowisata Dalam Perspektif Pelayana Publik. Jurnal Administrasi Publik, 3(12): 2123-2127. 
Hijriati, E, \& Mardiana, R. (2014). Pengaruh Ekowisata Berbasis Masyarakat Terhadap Perubahan Kondisi Ekologi, Sosial dan Ekonomi di kampung Batusuhunan. Sukabumi: Jurnal Sosiologi Pedesaan, 1(1): 146-159.

Jaffe, E., \& Pasternak, H. (2004). Developing wine trails as a tourist attraction in Israel. International Journal of Tourism Research, 6(4): 237-249.

Jambeck, J.R., R. Geyer, C. Wilcox, T. R. Siegler, M. Perryman, A. Andrady, R. Narayan, K. L. Law. (2015). Plastic waste inputs from land into the ocean. Science, 347 (6223): $768-771$

Marojahan, R. (2015). Hubungan Pengetahuan Masyarakat Tentang Sampah Dengan Perilaku Mengelola Sampah Rumah Tangga Di Rt 02 Dan Rt 03 Kampung Garapan Desa Tanjung Pasir Kecamatan Teluk Naga Kabupaten Tangerang. Forum Ilmiah, 12(1): 33-44.

Murianto, M, \& Masyhudi, L. (2018). Strategi Pengembangan Ekowisata Berbasis Masyarakat di Teluk Seriwe Lombok Timur. Jurnal Media Bina Ilmiah, 13(2): 913924.

Sugiyono. (2010). Metode Penelitian Pendidikan Pendekatan Kuantitatif, kualitatif, dan $R \& D$. Bandung: Alfabeta. 